\title{
12
}

\section{Formal and Everyday Participation in Foster Families: A Challenge?}

\author{
Elisabeth Backe-Hansen
}

\section{Children's Participatory Rights and Professional Work}

Children's participatory rights are defined in the UN Convention on the Rights of the Child (CRC), particularly Articles 12 and 13. While Article 12.1 concerns all children, Article 12.2 assures extra rights to children who become affected by judicial and administrative proceedings, for instance children placed outside their homes by Child Protection Services (CPS). Article 13 assures the child freedom of expression. Norway serves as the example in the chapter, illustrating a point that is valid across different countries. Since the CRC was adopted in 1989, The Norwegian Parliament has amended Norwegian legislation, and incorporated the CRC in the Human Rights Act (2003), and Grunnloven (the Constitution) (2014), which has precedence over other national legislation. The Grunnloven states that

E. Backe-Hansen ( $\square)$

Norwegian Social Research, Oslo Metropolitan University, Oslo, Norway e-mail: ebha@oslomet.no 
Children have the right to respect for their human dignity. They have the right to be heard in questions that concern them, and due weight shall be attached to their views in accordance with their age and development. ( $\$$ 104, para. 1)

In addition, legal requirements following from various other laws may be relevant, concretizing the rights defined by the CRC for more specific purposes. In Norway, for instance, there is the Kindergarten Act, the School Act, the Health Care Act and the Child Welfare Act. The last has been amended several times during later years, resulting in quite detailed regulations about children and young people's participation when they are in contact with CPS. I return to this Act below, since this chapter concerns foster families, but I will not discuss consequences of the other legal requirements here.

The overarching theme of this book is how the principles of the CRC can become an integral part of all professional child welfare and child protection work, in ways that ensure that these principles are implemented in practice. The CRC states that foster care is the preferred alternative when a child or a young person needs to be looked after by those other than their family of origin. This is the case in Norway and many other European countries. Most foster parents have children of their own, and these children as well as foster children have participatory and other rights accorded to them by the CRC, ensuing legislation and further regulations. Thus, one important question is what happens when the formal approach to participation, which follows from the regulations of the Child Welfare System, enters the private sphere where children's participation evolves as part of the process of growing up in a family, and as part of the relationship between parents and children. This issue has been only scantily addressed in the literature, where it is far more common to investigate to what extent foster children's formal participatory rights are assured before and during placement.

The chapter seeks to address this lack of knowledge through discussing the intersection between formal and everyday participation in foster families, and how the relationship between foster children, foster parents and other children in the foster home may be influenced by this. For the purposes of this chapter, a relational perspective on children's 
participation is useful because it serves to highlight both similarities and differences between foster children and children who already live in the foster family as both are children in relation to the same adults. This view has become more and more prominent during the last 10-15 years (Fitzgerald et al. 2010). After discussing this, I go on to describe foster children's participatory rights, and discuss how these may influence daily life in a foster family. Then I describe participation in decisionmaking as this is usually organized and negotiated, as a contrast to the formal and legalistic approach, before discussing possible consequences of the interaction between these two ways of implementing children's participation rights. Finally, I offer suggestions about how professional social work can address these issues. Although the Norwegian system is used as a case example, the issue of children's participatory rights in the intersection between being a public and private family should have wider relevance along with the importance ascribed to foster care as a care alternative.

\section{Rights, Relationships and Generations}

Many different rationales are offered about why children's participation and listening to children are appropriate and essential. In addition to the rights-based approach, which is the main focus of this book, better services, the promotion of citizenship and social inclusion, and personal and social education and development can be listed as worthwhile outcomes. Thus, a professional approach to children's participation may be inspired and justified by more than the CRC.

With reference to Warshak (2003), Mannion (2007) lists four different rationales, highlighting both advantages and disadvantages with regard to whether children actually participate. The first is dubbed The enlightenment rationale. Children have important information which may change decisions adults make on their behalf, again an important issue in relation to children as service users in the child welfare system. Such information provides important knowledge to adults about how they might better care for children's health, welfare and education, but at the same time what children say can easily be scripted by adults with their 
own agenda (Kjørholt 2002). She argues that discourses on 'children and participation' are deeply embedded in discursive fields other than children and their rights, as she found in her research about children's participation in local development in Norway. Here, an underlying agenda was how to maintain sustainable local communities in an era of centralization, rather than children's participation per se, making participation more tokenistic than real in Hart's (1997) terms.

The second rationale is political and is called the empowerment agenda, and is usually grounded in the CRC. In countering ideas about children as 'incompetent', this rationale positions children as complete individuals or citizens with adult-sized rights and responsibilities. If not seen in conjunction with children's needs, however, we risk an individualization of children's rights, which ignores children's all-important relationships with significant adults in their lives (Brannen and O'Brien 1995).

The third rationale is called the ambiguity of the citizenship rationale. This rationale argues that children's preparation for and participation in civic activities help them develop a sense of responsibility and obligation to society. Real citizenship may thus be seen as deferred while children prepare themselves through participation. But children may also be seen as citizens in the here and now, who as a minority group strive to be seen and heard while still children. School pupil councils may be seen as examples of practices where these competing views sit in tension-children can report that they participate in 'small' decisions, but not in really important ones, particularly not ones involving decisions about how to allocate the school budget (Holte 2009).

The three first rationales can all be understood as instances of an individualistic approach to children's participatory rights. On the other hand, criticism of these approaches, as exemplified by Kjørholt (2002) and Holte (2009), underlines how grown-ups play an important role in facilitating or limiting children's possibilities. Thus, it can be argued that it is not possible to leave the unequal power relationship between children and adults out of the equation (Punch 2005).

Warshak's (2003) fourth and final rationale is called outcomes for children / outcomes for adults, concretized as outcomes for adults and improved 
relationships between young people and adults. With regard to outcomes for children and young persons as a consequence of increased participation while growing up, not much research exists. In their research review, Vis et al. (2010) conclude that children's participation in planning and decision-making may have positive effects on their health, but the evidence is not very strong. However, research with children and young people, which focuses directly on their experiences with and views on participation, usually concludes that they want to participate, and want their voices to be heard, although they know that their wishes cannot always be granted. In their state-of-the-art review of children's and young people's participation within child welfare and CPS, van Bijleveld et al. (2015) sum up that the personal relationship between the child / young person and the social worker is mentioned as one of the most important facilitators for participation. Again, the relational perspective comes to the fore.

We know that relationships are fundamental in families, both for good and bad; between parents and children, between siblings, and between other members of the family network. Thus, it is easy to imagine that children will reflect on their participation within their families as part of the ongoing relationship with parents and siblings (BackeHansen 2009; Sagøe 2008). However, attempting to understand children's participation in a relational perspective has not been very prominent in the research literature until the last 15 years or so (BackeHansen 2011; Bell 2002; Élodie et al. 2017; Fitzgerald et al. 2010; Mannion 2007).

If we accept a relational perspective on children's participation, we also need to include context. This means reframing discourses about children's participation to include adults as important players, or so-called generationing practices that help us delineate between the generations, position us as adults and children, and demarcate how we relate to each other at different ages (Mannion 2007). Wyness (2012) advocates an interdependent and intergenerational approach to children's participation, recognizing the respective roles and positions of children and adults. Since foster children enter into relationships with both foster parents and foster siblings, this seems like a useful approach. 


\section{Formalized Participation for Children in Foster Care}

\subsection{Legislation and Regulations}

Children in contact with Norwegian CPS have a series of participatory rights grounded in the CRC Article 12.1 and 12.2. A social worker is responsible for ensuring these rights in his or her work with a family, while judges are responsible for hearing the child or young person directly, or through appointed experts or a guardian ad litem, when a case is contested and brought into the legal system. Here, I will limit my discussion to instances of participation related to foster care placement and children's lives as foster children after a placement decision has been made, and a child or young person is to be part of a new family.

Besides the overarching laws mentioned in the introduction, the Child Welfare Act, together with regulations, accords several rights to children within the remit of CPS. The child has a right to participation, which means being given sufficient and adapted information, and the possibility to freely voice his or her point of view (cf. CRC Article 13). The child is to be listened to, and his or her point of view is to be taken into consideration in accordance with age and maturity. Further, CPS are obligated to inform the child, as early as advisable and in ways the child understands, about situations where he or she can participate, the case and his or her situation, possible services and rights, and finally the choices and decisions which have to be made, and the consequences of these.

In other words, existing regulations describe a rational decision-making process following steps of information and choice, based on knowledge about possible alternatives based on available information. As well, participation is to be seen as a process that goes on throughout the case. Although the regulation stresses the right to participation in the case as a whole, themes that are important from the point of view of CPS are underlined. The elements in the text are case-driven, not seen in relation to what may be important in children's daily lives. The decision context is fairly narrow, nor do the regulations problematize how children's 
relationships may influence their ability and desire to participate in these case-based processes.

The person who is responsible for hearing the child must talk to him or her, with special attention to children who may have difficulties in understanding the situation and voice their point of view. Further, the perspective and opinions of the child have to be included in the assessment of the child's best interests, and taken into account in accordance with age and maturity, and the child is to be informed about decisions that are made and why.

Children must not be pressurized to participate, although CPS must document the child's participation as part of the case notes, of which an important part is the obligation to speak with the child if he or she is to be consulted. Thus, the focus and drive is on ensuring the child's participation, and alternatives in case the child refuses to participate are not addressed. The question may as well be raised as to whether participation really is voluntary. Nor is there any discussion about possible situations when participation may even be contrary to a child's best interests.

\subsection{Enforcing Foster Children's Participatory Rights}

The Child Protection worker is responsible for ensuring foster children's participation rights. This entails giving a child or young person age-appropriate and understandable information about his or her situation as a whole, and what will probably happen over time. As well, it entails having contact with foster children to ascertain their views about their life and their situationnot only in a 'one-off' fashion, but again as a process over time.

Information from the child or young person has to be part of the ongoing casework, and will, thus, be available to parents and foster parents as well. Some themes are particularly salient, particularly if there are new decisions to be made about the case from time to time. Parents may ask to have their child return home, or there will be discussions about the best way of organizing contact with the family of origin or siblings living elsewhere. These are emotionally charged issues, where the outcome and the justification for decisions that are made will influence the well-being 
of both children and adults. This implies that children's participation can entail more than just talking to them, and raises the question of the kind of relationship that needs to be established between social worker and child in order to make participation a positive experience for the child as well as ensuring that the child feels able to talk openly (Bakketeig and Bergan 2013; Bergan 2017).

In addition, a foster child should be able to talk about how she or he likes the foster home, whether there are any problems at home, at school or with friends, leisure time activities, holidays or other ordinary matters. How social workers discuss such themes with foster children has not been much researched, perhaps because of the ongoing focus on more formal participatory rights.

In addition to the social worker, a foster child in Norway is entitled to have a personal contact which follows the child directly, and is supposed to be a person to talk to if things are difficult in the foster home. Neither needs to actually see the children more than a few times a year. Children in care may as well be allowed to choose their own so-called 'person of trust', who can, for instance, accompany them to meetings and be a spokesperson for them. This means that even when there are no conflicts involving the court system, both the caseworker, the contact person and perhaps a person of trust will be involved in the foster home to safeguard children's interests in general, not only their participatory rights.

To sum up, children move into foster care with a set of legal expectations connected with participation that are formal, accompanied by several adults who have the authority to enforce their fulfilment. These expectations concern the relationship between the child, his or her parents, the social worker and the legal and professional aspects of the case. At the same time, the implementation of participatory rights concerns the foster family's daily life in many ways, which I will elaborate in more detail below.

\section{$4 \quad$ Participation as a Natural Part of Everyday Family Life}

Family life exemplifies how provision, protection and participation are intertwined as children grow up, and how the relative balance between the three shifts over time until a young adult is expected to fend for 
herself or himself. Typically, children will be successively more involved in decisions that are made within the family as they grow older, and their influence on the outcome will increase, albeit in different ways, depending on the type of decision that is being made. Children may also achieve some age-specific legal rights before they attain their majority. For instance, in Norway young people can decide how to use money they have earned themselves from age 15, and the age of sexual consent is 16 , which is also the age when one is allowed to start taking driving lessons with a grown-up.

\subsection{Age and Type of Decision Matter}

In Western countries a pre-school girl might well be allowed to decide whether she will wear trousers or a dress in kindergarten, but as long as the children are small, parents will usually decide unilaterally if they want to move the family somewhere else, for instance, or make other more lifechanging decisions. This exemplifies how participation in decisionmaking within a family will vary according to the kind of decision that is being made, and the age of the children. In addition there will be an interplay between the parents' views on how and when their children should be involved, which will, of course, vary as well, as will children's agency in demanding to become involved. But within such variation, it is possible to find some research on how children and parents 'do' participation in their daily lives.

The relational and generational aspects of participation which were discussed above become obvious in research on how decisions are negotiated in families. In her Scottish study, Punch (2005) gives several examples of children who discuss parental authority and accepts that parents have authority over their children, much more so than for instance an elder sibling over a younger one. This might be understood within the context of protection, with children thinking that their parents are motivated by an earnest concern for their best interests, but also within the context of power relationships. Sagøe (2008) did a study of 52 Norwegian primary school children aged 7 to 12 , and their participation in family decision-making. Her general findings were that the children felt they 
could ask and make suggestions, and discuss with their parents. Many situations were open for negotiation as well, and the children described instances when their parents listened to them if they found their arguments good. At the same time the parents had the deciding power. The children did not always feel that their parents justified their decisions properly, or they felt that parents might use vicarious arguments. At the same time the younger children preferred the situation as it was, while the older children would have liked more influence.

Sagøe (2008) found that children did participate in some everyday areas, for instance when it came to deciding what to have for dinner, or the kind of goodies to be bought on Saturdays. The children could state their preferences when it came to choosing what clothes to buy, while their parents had a say when it came to cost, quality and to a certain amount style. The children also participated in the choice of leisure-time activities they were to join. The older, but not the younger children were in addition involved in deciding what to do during weekends and holidays. All the children had rules concerning when they had to come home, most had to tell their parents where they were, and come home at the appointed time. Bedtime was usually not open for discussion, in the sense that the parents usually decided a time limit or a usual bedtime. Many parents wanted their children to join in at least one leisure-time activity, which in Norway will usually be some kind of sport, and some were not allowed to quit this even if they wanted to. In addition, some of the older children had duties at home, but were not allowed to decide which.

One will expect children's autonomy and influence to increase with age. There are limits to how long children can be forced to participate in activities they are not motivated for, and one expects children to become successively more competent as they grow up. Thus, negotiation and efforts to motivate will become much more important over time than just using parental authority.

At a more general level, Sagøe (2008) found that parents organized their children's lives based on time. They decided when the children had to get up in the morning, when they had to come home from school/after school activities, when they were to have dinner, come home in the evening and go to bed. As well, many parents set limits to how much time the children could spend watching TV, use a PC or play data games. The 
oldest of her participants were 12-13 years old, however, so one would expect the parents' monitoring of their children's time use to become less intense with age although parents of teenagers still want to know the whereabouts of their children.

\subsection{Participation Is Relational and Entails Compromise}

When children are asked directly about what participation means to them, the relational dimension becomes evident. Backe-Hansen (2009) asked 4410 - and 13 year olds to write short essays about how they would define 'participation'. Although particularly the oldest girls wrote more in detail, there were not fundamental differences between the responses.

First, it was obvious that the children themselves understood participation as a relational phenomenon. They gave many examples that underlined the importance of achieving agreement, that nobody has to give in. They could motivate others to join them, or they could be happy to have a say. Examples were given in relation to parents, siblings or friends. They gave examples from their daily lives, like where to go on holiday, what to eat for dinner or what to do after school. The examples underlined the importance of making decisions in collaboration with others.

As well, the examples underlined that participation is a process that takes time, and does not necessarily end well. The children described how they could discuss with their friends over time, and how agreements could be reached and undone, and how they sometimes had to talk for a long time before reaching an agreement. Sometimes they did not manage to agree, and had to find a workable compromise-or leave.

The participants in this study were specifically asked about participation, and were not asked to describe limits to participation or situations where they were not invited to participate. Still their examples correspond well with the findings from Sagøe's (2008) study, which was based on interviews. The focus on relational aspects of participation also resonates well with more recent theorizing about children's participation (Fitzgerald et al. 2010). 
Seeing decision-making in the daily lives of families in relation to Warshak's (2003) four categories, the final one, outcomes for children / outcomes for adults, seems most appropriate since it concerns improved relationships between adults and children through the involvement of children. The research literature does not necessarily discuss this in a children's rights context, but rather as a question of roles and expectations of adults and children, negotiations and processes within an ongoing and changing, close relationship.

Parents will also see participatory rights in relation to responsibilities, thus a give-and-take relationship with parameters that may be defined by both grown-ups and children. Part of raising children is to teach them that you have to contribute with something to earn the right to increased privileges, and you may have to accept the withdrawal of privileges if you do not contribute. This does not pertain to all rights, as children have a series of rights that do not presuppose this kind of exchange. But the issue of fair distribution of responsibilities as well as rights, preferably in agreement between all family members, will be important within a family setting.

\subsection{The Decision to Become a Foster Family}

The decision to become a foster family can involve many persons- the foster parents themselves, their children, other family members and members of their social network. The processes prospective foster parents have to go through in particular before a child or young person actually moves in entail a transition from being a family with the right to define their own family life with large degrees of freedom, to being a 'public' family. As such, the foster family has to submit to assessment and control by CPS through formal assessments, contracts and counselling and supervision.

One question is to what extent the foster family's own children are involved as actors in this process, or to what extent the decision to foster is seen as primarily a grown-up concern, which will be presented to the children as more or less a fait accompli. In their literature review about the impact of fostering on foster carers' children, Höjer et al. (2013) point out, first, that being involved in the decision to foster enhances 
subsequent adaptation. This was a key finding in the 17 studies that were included in the review. Children and young people need to be involved in family discussions concerning the decision to foster, and should not be seen as less significant or passive members of the family. Second, the review shows that being informed about fostering and about each particular child beforehand reduces conflicts. These findings underline the need for collaboration between prospective foster parents and social workers about how foster parents' own children can be involved in the process leading to a placement. Consequently, the second question is to what extent social workers see prospective foster parents' own children as important participants in the placement process, and to what extent only older children are involved.

Nordenfors (2016) combined qualitative and quantitative methods and investigated the experiences of foster parents' own children of growing up with foster siblings. Two-thirds of the 684 children who answered a questionnaire reported being asked their opinion by their parents before the decision to start fostering was made. Some explained that they were too young, however, although how young they actually were, varied. The article does not describe these processes in detail. On the other hand, the foster parents' own children could be described as non-participants in the official part of the process. As many as 44 per cent of the children had not been asked by the social worker what their thoughts were, while 29 per cent had been asked and 27 per cent did not know. As might be expected, the oldest children were most frequently consulted by the social workers. This meant that many of the children were deprived of the possibility of information from professionals about what it means to be a foster child, as well as what it means to get a foster sibling - information which might be crucial to later adaptation, particularly if the gap between expectations and reality becomes too large (Höjer et al. 2013).

\section{Interactions in Everyday Life}

What, then, are the most important differences between being a foster family and a family without foster children, and how do they affect interactions in everyday life? First, being a public family with a renegotiable 
contract, subject to being overseen by CPS, takes authority away from the parents in relation to the foster child. Although foster parents are supposed to make everyday decisions concerning a foster child, they still have to relate to social workers and to parents when these have retained parental rights. If, for instance, a child asks where he or she is going to spend the next summer holidays, or whether it is OK to start playing football, the foster parents cannot answer directly, but must check with the social worker.

This loss of authority on the part of the foster parents illustrates that foster parents do not have the same authority over foster children as they have over their own. For instance, being oppositional and wanting to move somewhere else is not uncommon amongst teenagers living with their parents. In these situations, parents might well want to exert their authority and refuse this as an alternative until a child gets older. This is not possible with a foster child, who will, in addition, have the possibility to engage the social worker or the person of trust because of the way participatory rights are defined — and might end up moving somewhere else. Sometimes this is the right decision, but in many other situations, the young person might be significantly worse off losing what has been a stable home over time. Some young adults can also look back and think that a precipitate move was a bad decision, since she or he could not envisage all the consequences at the time.

The existence of public persons who have the right to visit the family and have opinions about their life will as well influence the relationship between foster children and the other children. Not much is known about how these influences unfold in practice, but a couple of reflections may be useful. One important question concerns imbalance-that a foster child and another child in the family have different status. While the former partly lives this 'public childhood' as it were, the other children in the foster family must relate to the parents as they always have done, with the parents having authority that can be questioned by the children, but which does not depend on acquiescence from outside of the family. Consequently, foster children and the other children will have different ways of negotiating issues that may arise, and both may feel that they are unfairly treated compared to the other. 


\section{Professional Practice with All Children in a Foster Home}

When a foster home is approved, CPS presuppose that children will be provided for and suitably protected. Ensuring this is part of the run-ofthe-mill system of following up foster children. However, ensuring participatory rights is something over and above this. Thus, I suggest three guiding principles for a rights-based, professional practice in foster care with regard to participatory rights.

The first is to see all children in a foster home on an equal footing as bearers of participatory rights, even though social workers do not have any responsibility for the children already there, and even though foster children are assured extra rights according to Article 12.2. Although there will be case-relevant matters that are just as relevant for the foster child, life in the foster family will entail questions where it may be important for all the children in the family to be able to talk with the social worker, as equal members of the child generation. In addition comes the findings from research (Höjer et al. 2013; Nordenfors 2016) showing that informing children already in the home and including them as actors improves the probability of adaptation on their part. Although there will always be room for conflict, as in any family, it can help the children to feel that they are heard and seen by someone who actually has some authority. As well, this might help them accept that foster children may need extra attention and work, which gives their parents less time for them.

The second principle concerns parental authority on the part of the foster parents. Balancing parental authority between CPS, the parents and the foster parents can be tricky, but if a child is to have a stable foster home, the carers need to be able to exert sufficient authority as responsible parents, even or perhaps particularly when there are conflicts. In Norway, foster parents do not have this authority, since any conflict may end up as a question of what jurisdiction foster parents have, whether the contract should be cancelled and so on.

The third and overarching principle needs to be participation as relational and contextual, as discussed earlier in this chapter. Foster children 
need to be incorporated into the foster family. This is done through engaging with the daily life there, including taking part in decisions that are made, and not remaining aloof. For the foster parents to engage with their new family member, they need to feel that he or she belongs, which means fully incorporating them in their daily life with all the usual ups and downs. This underlines the need for foster parents to be allowed to involve foster children in these processes, as well as being allowed to act as parents.

To sum up, these three principles entail changing the balance between social worker, foster parents and all children in the foster home in order to ensure professional work with children's participatory rights. All children need to be treated equally, foster parents need more authority and social workers need to involve the family as a whole, not just the foster child.

\section{References}

Backe-Hansen, E. (2009). Barns medbestemmelse sett med barns øyne [Children's participation seen through the eyes of the children]. In R. Hjermann \& K. Haanes (eds), BARN (pp. 52-61). Oslo: Universitetsforlaget.

Backe-Hansen, E. (2011). Teoretiske perspektiver i synet på ungdoms medvirkningen litteraturgjennomgang [Theoretical perspectives on young people's pariticipation-A literature review]. Vedlegg til NOU 2011:20—Ungdom, makt og medvirkning.

Bakketeig, E., \& Bergan, L. T. (2013). Om ungdoms medvirkning ved plassering i fosterhjem [Young people's participation when placed in foster care]. In E. Backe-Hansen, T. Havik \& A. B. Grønningsæter (eds), Fosterhjem for barns behov. Rapport fra et firearig forskningsprogram (pp. 85-101). Oslo: NOVA, rappot 16/2013.

Bell, M. (2002). Promoting children's rights through the use of relationship. Child \& Family Social Work, 7, 1-11.

Bergan, L. T. (2017). Barns medvirkning under barnevernets omsorg. En kvalitativ intervjuundersøkelse av hvordan barn i fosterhjem opplever à medvirke [Children's participation in care. A qualitative study]. Oslo: VID vitenskapelige høgskole, Master's thesis. 
Van Bijleveld, G. G., Dedding, C. W. M., \& Bunders Aelen, J. F. G. (2015). Children's and young people's participation within child welfare and child protection services: A state-of-the-art review. Child \& Family Social Work, 20, $129-138$.

BLD. (2014). FOR-2014-06-01-697. Forskrift om medvirkning og tillitsperson [Regulation about participation and a person of confidence]. Oslo: Ministry of Children and Equality.

Brannen, J., \& O’Brien, M. (1995). Childhood and the sociological gaze: Paradigms and paradoxes. Sociology, 29, 729-737.

Élodie, M., Paulsen, V., \& Goyette, M. (2017). Relationships matter: Understanding the role and impact of social networkds at the edge of transition to adulthood from care. Child and Adolescent Social Work Journal, 54, 573-582.

Fitzgerald, R., Graham, A., \& Taylor, N. (2010). Children's participation as a struggle over recognition: Exploring the promise of dialogue. In B. PercySmith \& N. Thomas (Eds.), A handbook of children's participation (pp. 295-305). London: Routledge.

Hart, R. (1997). Children's participation: The theory and practice of involving young citizens in community development and environmental care. Firenze: Innocenti Research Institute.

Höjer, I., Sebba, J. \& Luke, N. (2013). The impact of fostering on foster carers' children. An international literature review. Oxford: University of Oxford, Rees Centre for Research in Fostering and Education. Downloaded November, 2017.

Holte, J. (2009). Barns deltakelse i skolen—slik det fortoner seg fra barns synsvinkel [Children's participation in school—As the children see it]. Bergen: Universitetet i Bergen, Senter for barnevernsstudier. Masteroppgave.

Kjørholt, A.-T. (2002). Small is powerful. Discourses on 'children and participation' in Norway. Childhood, 9, 63-82.

Mannion, G. (2007). Going spatial, going relational: Why 'listening to children' and children's participation need reframing. Discourse: Studies in the cultural politics of education, 28, 405-420.

Nordenfors, M. (2016). Children's participation in foster care placements. European Journal of Social Work, 19, 856-870.

Punch, S. (2005). The generationing of power: A comparison of child-parent and sibling relations in Scotland. Sociological Studies of Children and Youth, 10, 169-188.

Sagøe, U. (2008). Barnets stemme hjemme. Om barneskolebarns stemme hjemme sett fra barns synsvinkel [Children's participation at home-As the children see it]. Bergen: Universitetet i Bergen, Senter for barnevernsstudier. Masteroppgave. 
Vis, S.-A., Strandbu, A., Holtan, A., \& Thomas, N. (2010). Participation and health-A research review of child participation in planning and decisionmaking. Child \& Family Social Work, 16, 325-335.

Warshak, R. (2003). Payoffs and pitfalls of listening to children. Family Relations, 52, 373-384.

Wyness, M. (2012). Children's participation and intergenerational dialogue: Bringing adults back into the analysis. Childhood, 20, 429-442.

Open Access This chapter is licensed under the terms of the Creative Commons Attribution 4.0 International License (http://creativecommons.org/licenses/ by/4.0/), which permits use, sharing, adaptation, distribution and reproduction in any medium or format, as long as you give appropriate credit to the original author(s) and the source, provide a link to the Creative Commons license and indicate if changes were made.

The images or other third party material in this chapter are included in the chapter's Creative Commons license, unless indicated otherwise in a credit line to the material. If material is not included in the chapter's Creative Commons license and your intended use is not permitted by statutory regulation or exceeds the permitted use, you will need to obtain permission directly from the copyright holder.

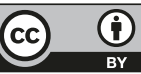

